DOI: $10.15642 / J I I S .2016 .10 .1 .37-62$

\title{
THE DEBATES SURROUNDING THE ACCOMMODATION OF ISLAMIC ADULTERY CRIME AND PUNISHMENT INTO INDONESIAN CRIMINAL CODE
}

\begin{abstract}
Ishaq
IAIN Sulthan Taha Saifuddin, Jambi - Indonesia | ishaqdama@gmail.com

Abstract: The current bill of Indonesian Criminal Code is going to be sanctioned in no time. In the draft, the crime of adultery has leaned to Islamic criminal law in many respects, although the punishment is far more lenient. The definition of adultery has been broadened to cover fornication and cohabitation. Heavier punishment is applicable although not as severe in Islamic criminal law. When the draft is sanctioned, the Code arguable will be deemed more Islamic. This paper will discuss adultery as a crime in Indonesian Criminal Code as it is inherited from the Dutch, Islamic criminal law, and its stipulation in the Draft of Indonesian Criminal Code. The article also highlights the controversy surround the issue along the way.
\end{abstract}

Keywords: Adultery crime, Islamic criminal code, Indonesian criminal justice

\section{Introduction}

There are several purposes of criminal justice. Criminal justice must serve as (1) preventing people from becoming victims of crime, (2) solving criminal cases so that the community is satisfied that justice has been done and the guilty party is convicted, and (3) making effort that those who have committed a crime not to repeat the crime. ${ }^{1}$ To

\footnotetext{
${ }^{1}$ Mardjono Reksodiputro, Hak Asasi Manusia Dalam Sistem Peradilan Pidana (Jakarta:
} Pusat Pelayanan Keadilan dan Pengabdian Hukum Universitas Indonesia, 1994), p. 84. 
make sure that the law is observed, values of society should be accommodated in criminal code. ${ }^{2}$ This is in line with the volkgeist theory argued by historian Friedrich Carl von Savigny, that the concept of the law must reflect 'the spirit of a nation', ${ }^{3}$ Furthermore, Von Savigny believes that laws must be derived from custom and belief of the people in which the law is implemented. ${ }^{4}$

The Current Indonesian Criminal Code is inherited from the Dutch. In many respects, it is contradictory to Islamic criminal law widely held by Indonesian Muslims. After independence, especially when devotion to Islam and its teachings resurges since the 1980s, this is obviously problematic since the majority of Indonesians are Muslims. Quite considerable number of Muslims demanded the accommodation of Islamic law in the national legal system. Along with the national program of legislation which has been initiated since 1977 and later intensified with the enactment of Law 10/2004 on Legislation, ${ }^{5}$ Indonesian Criminal Code is one of the legislation agenda. One aspect of Criminal Code that differ starkly with Islamic criminal law is adultery. Consequently, this will be the subject of revision in the planned legislation.

The urgency of revising adultery stipulation in the existing criminal code is not only based on religious consideration. The spread of sexual relationship outside marriage among youngsters, prostitution and cohabitation have created several negative repercussions, such as sexually transmitted diseases, illegal abortion, raising the rate of divorces, and abandonment of illegitimate children. ${ }^{6}$ Many elements

2 Tongat, Pidana Kerja Sosial dalam Pembaharuan Hukum Pidana Indonesia (Jakarta: Djambatan, 2002), p. 25.

${ }^{3}$ Muhamad Erwin, Filsafat Hukum Refleksi Kritis Terhadap Hukum (Jakarta: RajaGrafindo Persada, 2011), p. 190.

${ }^{4}$ Soerjono Soekanto, Pokok-pokok Sosiologi Hukum (Jakarta: RajaGrafindo Persada, 2001), p. 33.

5 BPHN, Tiga Dekade Prolegnas dan Peran PBHN (Jakarta: BPHN, 2008), p. iv.

${ }^{6}$ A survey conducted in 33 provinces in 2008 reported that as many as $63 \%$ of high school students have conducted sexual relationship and $21 \%$ of whom has undergone abortion which is forbidden in Indonesia, read Republika Online, 63 Persen Remaja Berbubungan Sex (20 December 2008), http://www.republika.co.id/berita/shortlink/21526, viewed on 21 February 2016. The number of pregnancy outside marriage among youngsters is also high at $20 \%$. This contributes to high rate of labor mortality in Indonesia. 
within Indonesian community call for correcting this situation by returning to religious values. ${ }^{7}$ In doing so, they believe that certain aspects of Islamic criminal law must be accommodated. This is because Islamic criminal law provides more strict rules against indecency-related crimes (such as adultery, fornication, cohabitation, and prostitution) with considerably sterner punishment as well. By tightening the grip of legal institution on those crimes, they believe that those crimes will be mitigated and the excesses are contained. However, some other elements in the society maintain that the state must not intervene too deep into personal and private lives of its citizens in these so-called victimless crimes. Moreover, in many states, the crimes have been decriminalized. Expansion of adultery-related crimes will only breach the line of what constitutes as public welfare and private business. Thus, the state might be stumbled upon violation human rights.

To give the context of the bill of criminal code and the debates surrounding it, the existing criminal law, especially articles related to adultery will be discussed. And Islamic criminal law of zina (adultery and fornication) as well as its punishment will be explained.

\section{Adultery Definition on Criminal Code}

Adultery crime is stipulated in Article 284 of the Criminal Code in the chapter entitled Crimes against Decency. The article stipulates as follows:

(1) By a maximum imprisonment of nine months shall be punished:

1. (a.) any married man who knowing that article 27 of Civil Code is applicable to him, commits adultery; (b.) any married woman who commits adultery;

2. (a.) any man who takes a direct part in the act knowing that the guilty co-partner is a married; (b.) any unmarried woman who takes a direct part in the act knowing that the guilty copartner is married and that article 27 of the Civil Code is applicable to him. ${ }^{8}$

\footnotetext{
7 See for instance, Hasbullah F. Sjawie, 'Delik Perzinahan Menurut KUHP dan Perkembangannya', Hukum dan Pembangunan, 1, 26 (Pebruary 1996), pp. 27-38.

8 Article 27 of Civil Code: At any one time a man may only be bound to one woman and a woman bound to one man in a marriage.
} 
(2) No prosecution shall be instituted unless by complaint of the insulted spouse article 27 of the Civil Code is applicable, with the time of three months by a request for divorce or severance from board and bed on the ground of the same act.

(3) In respect of this complaint articles $72,973,{ }^{10}$ and $75^{11}$ shall not be applicable.

(4) The complaint may be withdrawn as long as the judicial investigation has not commenced.

(5) If article 27 of Civil Code is applicable to the spouse, the complaint shall not be complied with as long as the marriage has not been severed by divorce or the verdict whereby severance from board and bed has been pronounced, has not been final.

Adultery under Article 284 clause (1) of the Criminal Code can only be considered as a crime when there is sexual intercourse done by a man and a woman. ${ }^{12}$ Furthermore, this offence as defined in Article 284 of the Criminal Code must meet these following elements; (1) the requirements that the adulterer has been married; (2) the complaint from the husband or wife of the adulterer; and (3) the adulterer partner must know that the partner is a married person. Thus under the provisions of Article 284 of Criminal Code, the legally mature men and women who are both unmarried and having sex outside the bond of legalized marriage is not categorized as adultery and then is not an offence. ${ }^{13}$ Thus, the act of sexual intercourse by two persons, namely

\footnotetext{
9 Article 72: As long as the person whom a crime has been committed which is to be prosecuted only upon complaint, has not reached the age of sixteen and is also a minor, or as long as the person otherwise then by reason of prodigality has been placed under guardianship the person authorized to file the complaint shall be his or her legal representative in private affairs.
}

10 Article 73: If the person against whom the crime has been committed dies within the term prescribed in the following article, the prosecution may, without extension of said term, take place upon complaint of the parents, of the children or of the surviving spouse, unless it were evident that the deceased did not wish the prosecution to take place.

11 The person who files the complaint remains competent to withdraw the complaint during three months after the filling date.

12 P.A.F. Lamintang, Theo Lamintang, Delik Delik Khusus Kejahatan Melanggar Norma Kesusilaan dan Norma Kepatutan (Jakarta: Sinar Grafika, 2009), Second Edition, pp. 7980.

${ }^{13}$ Ibid., pp. 84-85. 
woman and man who each of them has been married is fornication, because the act of adultery is considered a breach of fidelity in marriage, although at the time of the adultery incident they are in the process of divorce. Article 284 specifies that within a period of three months since they have filed for divorce, the act is still regarded as adultery. Then R. Soesilo explained that adultery is sexual intercourse done by married man or married woman to a woman or man who is neither his wife nor her husband, who performed consensual and no compulsion for each other. ${ }^{14}$

\section{Adultery Definition in Islamic Criminal Law}

Adultery in Islam is part of hudud (a punishment fixed in the Quran and hadith for crimes considered to be against the rights of God) offence. The term adultery in Arabic is etymologically a masdar (noun) form of the word "نجنى" (fajara) or evil/obscene. ${ }^{15}$ While terminologically, the definition of adultery proposed by Abd al-Qadir 'Ouda, an expert of Islamic criminal law, cited in Enceng Arief Faizal and Jaih Mubarok is any forbidden sexual intercourse. ${ }^{16}$ Likewise, Ahmad Wardi Muslich explains that adultery is any sexual intercourse outside wedlock and punishable with sanctions, whether the adulterer is married or not, or consensually performed or not. Thus, the definition of adultery in the view of Islamic law is much broader than that of contained in Article 284 of the Criminal Code. The definition of adultery in Islamic criminal law is divided into ghairu mubshan, which in English called fornication and mubshan or adultery. While ghairu mubshan is unlawful sexual intercourse by unmarried persons, mubshan adultery is unlawful sexual intercourse by married persons. Prohibition of adultery in Islamic criminal law is very strict, closely related to efforts to uphold Islamic morality which concerns person, family, society and the nation. Adultery is a major sin in Islam, alongside with idolatry, homicide and other major sins. Therefore, both types of adultery are punishable with heavy penalties.

\footnotetext{
${ }^{14}$ R. Soesilo, Kitab Undang-undang Hukum Pidana (KUHP) serta Komentar-komentarnya Lengkap Pasal demi Pasal (Bogor: Politeia, n.d), p. 209.

${ }^{15}$ Louis Ma'luf, al-Munjid fi al-Lughah wa al- A'lam (Beirut: Dar al-Masyriq, 1996) p. 308.

${ }^{16}$ In Enceng Arif Faizal, Jaih Mubarok, Kaidah Fiqh Jinayah; Asas-Asas Hukum Pidana Islam (Bandung: Pustaka Bani Quraisy, 2004), p. 117.
} 


\section{Punishment for Adultery in Criminal Code and in Islamic Criminal Code}

\section{Adultery Punishment in the Criminal Code}

In overview, adultery in the Criminal Code is considered a minor crime. It is merely a private offence which only concerns individuals in a marriage, namely husband and wife. This is because the Criminal Code that is applied now is a legacy of the Dutch colonialism. Therefore, the notion of adultery in the Code according Harkristuti Harkrisnowo reflects more to the values held by society in Western Europe in which the Code is originated than the values held by Indonesian society. ${ }^{17}$ It was enacted by the Dutch in Indonesia during colonial period. ${ }^{18}$ Originating as the Dutch Criminal Code, this continental legal Code was influenced by Roman law and canon law of the Catholic Church. The fact that adultery is deemed as crime proves this origin. Admittedly, as quoted by Sweeny, Douglas Greenberg states that adultery and fornication laws were originally cornerstones of a legal system that emphasizes religious morality. ${ }^{19}$ In the extreme cases, adulterer would be drowned in ancient Europe.

However, the religious-inspired laws in the Code is severely relaxed overtime. In XIX Century CE, individualism and liberalism swept Europe. Commitment to religious values as source of law diminished. Their impact on adultery law is significant. Personal life, including one's sexual life, had become a right of privacy which is guaranteed by constitution. This is a telling sign of a fundamental shift in society's value and culture. As a result, although this misconduct was still punished, it was not by death, but imprisonment. During XX Century, many European countries classified adultery as minor offence. Finally, starting the second half of the previous century, adultery ceased to be a

17 Harkristuti Harkrisnowo, "Tindak Pidana Kesusilaan dalam Perspektif Kitab Undang-Undang Hukum Pidana", in Muhammad Amin Suma (ed.), Pidana Islam di Indonesia; Peluang, Prospek dan Tantangan (Jakarta: Pustaka Firdaus, 2001), p. 181.

${ }^{18}$ The Code was introduced by the Dutch in 1918. It was originally named Wetboek van Strafrecht. After independence its applicability was sanctioned by Law No. 1/1946 for Java and Madura and Law No. 73/1958 for the rest or Indonesian territory. See Neng Djubaedah, Perzinaan dalam Peraturan Perundang-undangan di Indonesia Ditinjau dari Hukum Islam (Jakarta: Kencana, 2010), pp. 64-65.

${ }^{19}$ JoAnne, Sweeny, 'Undead Statutes: The Rise, Fall and Continuing Uses of Adultery and Fornication Criminal Laws', Loyola University Chicago Law Journal, 46 (2014), p. 131. 
criminal offence..$^{20}$ The last country to do so was Austria in 1997. ${ }^{21}$ The main reason for this abolition is twofold. The first, according to Friedman as reported by Djubaedah, is that indecency-related crimes had been considered as victimless crime in which adult people chose and no others were harmed. Every human being had the freedom to do with their personal lives including in sexual lives. ${ }^{22}$ The second is to provide energy to the legal enforcement in focusing on more imminent and serious crimes. ${ }^{23}$

Having sketched the historical background of the Criminal Code, since the Dutch introduced the Criminal Code to Netherland East Indies in 1918, the punishment of adultery in the Code had been considerably lenient. The leniency can be concluded from at least two aspects. The first is that it is stipulated in the article 284 of the Code that the maximum punishment is nine months of imprisonment. The fact that the punishment only sets the maximum limit of nine month of imprisonment indicates that the convicted adulterer will only punished no more than nine month of imprisonment. In many cases the punishment is less than this nine month of imprisonment. ${ }^{24}$ The second concerns the complaint aspect of the crime. Since adultery considered private offence, the Code considers adultery as a complaint-based crime. Thus, only the insulted spouse is allowed to

\footnotetext{
${ }^{20}$ According to JoAnne Sweeny, the case in the United States, however, is different. There are twenty states in which adultery and/or fornication is a crime. Few states maintain adultery statutes albeit unenforced. A few states repealed adultery or fornication statutes, whereas others maintain the statutes with less prosecution. See Sweeny, 'Undead Statutes, pp. 130-1

${ }^{21}$ Lenka Bezouskova and Antonin Lojek, 'Adultery and Fornication in Historical Perspectives, The Law Quarterly, 4 (2015), p. 261.

22 Djubaedah, Perzinaan Dalam Peraturan, pp. 204-5

${ }^{23}$ JoAnn Sweeny, 'Undead Statutes, p. 131

${ }^{24}$ For example, the verdict of Court of Banyuwangi district in East Java No. 476/PID.B/2011/PN.BWI dated September the $2^{\text {th }}$, 2011 on an adultery case only punished the adulterer with 4 (four) month of imprisonment. The verdict of Appeal Court of Medan North Sumatera No: 308/PID/2012/PT-MDN dated July the 31st, 2012 on an adultery case punished the adulterer with 2 (two) month of imprisonment. The verdict of Pelaihari district in South Kalimantan No: 05/Pid.B/2010/PN.Plh dated July 13rd, 2010 punished the adulterer with 7 (seven) months of imprisonment. The verdict of Unaaha district in Southeast Sulawesi No: 52/Pid.B/2013/PN.Unh dated August 30th 2013 punished the two adulterers with one month and fifteen days of imprisonment.
} 
report the crime. However, this complaint, as the article stipulates, may also be withdrawn by the victim as long as the case is not yet judicially investigated. However, R. Soesilo asserted that the authority has the right to prevent adultery so that law and order is preserved. ${ }^{25}$

Surely, the lenient punishment of adultery does not correspond with the principle of punishment in criminal studies. In the case of punishment according to Herbert L. Packer, the purpose of punishment is to deter the offender and to prevent further crime. ${ }^{26}$ Based on the above opinion, it is clear that each person who commits an offense should receive a punishment that is commensurate with his or her actions, and to prevent crime. In addition to punitive purpose, punishment according to Soejono is also to educate convicted criminals so they will not repeat their mistakes. ${ }^{27}$ Similarly, Mardani argues that the purpose of punishment in the philosophy of law are: (1) to deter people from doing crime, (2) to prevent other person from committing a crime, (3) to educate convicted criminals in order to become good people and contribute to community in good ways. ${ }^{28}$ Therefore, the Article 284 of the Criminal Code needs to be revised by accommodating legal reference that lives in the community. This is because the living law in the community that reflects the values prevailing in the society, should be adopted as law of the state..$^{29}$ On this basis, the values of Islamic law and customary law.

\section{Adultery Punishment in the Islamic Criminal Law}

In Islamic criminal law, the punishment against adultery is firmly and clearly stated in the Holy Quran and Hadith. Adultery as criminal offense is part of budud crime, the offence against God and society. Its punishment also has been determined by Allah in the Holy Quran and in Hadith. The punishment for fornicator is lashing, whereas stoning

\footnotetext{
${ }^{25}$ Soesilo, Kitab Undang-undang Hukum Pidana.

${ }^{26}$ Herbert L. Packer, The Limits of the Criminal Sanction (California: Stanford University Press, 1968), p. 36.

27 Soejono, Kejahatan \& Penegakan Hukum di Indonesia (Jakarta: Rineka Cipta, 1996), p. 38

28 Mardani, Penyalahgunaan Narkoba dalam Perspektif Hukum Islam dan Hukum Pidana Nasional (Jakara: RajaGrafindo Persada, 2008), pp. 71-2.

29 Mochtar Kusumaatmadja, Konsep-Konsep Hukum dalam Pembangunan (Bandung: Alumni, 2006), Second Edition, p. 10.
} 
to death is for adulterer. The legal basis for lashing as many as one hundred times is mentioned in the Holy Quran chapter 24:2.

While the basis law for determining stoning has been described in Hadith of the Prophet from Ubadah bin Samit, which means as follows:

"Take from me (accept punishment from me) Allah indeed has made a way for women: between unmarried and unmarried (fornication), the sentence is lashed one hundred times and is exiled for a year; between married and married persons (adultery) the sentence is lashed a hundred times and is then stoned. (narrated by Muslim)." ${ }^{30}$

The above hadith explains that the punishment of fornication is one hundred lashes times and exile for one year. Meanwhile the punishment of adultery is one hundred lashes and stoning to death. Thus, there is great difference in punishment between fornication and adultery. Unlike fornication, an adulterer should be able to take care of his or her sexual desire to avoid misconduct because he or she has already married. Thus, adultery will harm and defame the family. Nevertheless, both adultery and fornication remain highly reprehensible by Islam and heavy punishment is applicable without tolerance as stipulated in the Holy Qurán 24:2 which means: "And do not feel compassion for both of them so as to prevent you in carrying out the Allab's law".

The harsh criminal sanctions for fornication and adultery in Islam because it is a disgraceful act and decrease humanity in general. In Islamic perspective, if adultery is not necessarily prohibited, human dignity will be compromised because the rules governing marriage in society will be barred. ${ }^{31}$

To convict adultery and fornication, however, the procedure in Islamic criminal law is demanding and strict. It requires at least four Muslim mature male witnesses who all with their own eyes see the sexual intercourse and later provide correspondingly univocal testimony. By sexual intercourse means the penetration of penis into vagina. ${ }^{32}$ Testimony of less than required, is not valid. In fact, this type

\footnotetext{
${ }^{30}$ Muh. Syarief Sukandy, Terjemah Bulughul Maram Fiqih Berdasarkan Hadits (Bandung: Almaárif, 1978), Third Edition, p. 449.

${ }^{31}$ Makhrus Munajat, Hukum Pidana Islam di Indonesia (Yogyakarta: Teras, 2009), p. 136.

32 Al-Sayyid Sabiq, Fiqh al-Sunnah (Cairo: Dar al-Hadits, 2004), p. 724.
} 
of defamation will be charged of false adultery (and fornication) accusation (qadraf) which is punishable with equally severe punishment. This defamation offence is also clearly determined in the Holy Quran chapter 24:4-5 with the penalty of eighty lashes and the rejection of the offender's testimony ever after. ${ }^{33}$ Furthermore, as stated by Rahmat Hakim, that the essence of punishment for the adulterer according to Islam are; firstly, prevention and retaliation (arradu waz zabru), and secondly, the reconciliation and education (al-ishlah wat-Tahdheeb) ${ }^{34}$. The purpose of the punishment is twofold, that the adulterer should not do the same mistake in the future and additionally, it is also a deterrence for other people for not doing the same.

In any case, an opinion that adultery (and fornication) punishment assigned Koran and Hadith is very heavy indeed is true when compared with the sanctions contained in Article 284 of the Criminal Code. The punishment is imprisonment for maximum nine months and included as criminal complaint. Many argue that rampant prostitution, cohabitation, and other extra marital sexual relationship in Indonesia is mainly caused by this lenient punishment. This is an irony for a country with majority Muslim population. Therefore, some conservative Muslims are on the opinion that Indonesia should seriously consider applying Islamic Criminal Law of adultery (and fornication), both in terms of definition and punishment. ${ }^{35}$

\section{Muslims Divide on the Issue of Application of Islamic Law in Indonesia}

However, Indonesian Muslims are far from consensus on this matter. While in the past the disagreement on the applicability of Islamic teaching occurred between Muslims and the secular nationalists, ${ }^{36}$ nowadays Muslims are divided at least into conservativefundamentalists in one side and modern-liberals in the other. The split among Muslims can be attributed to two intellectual and religious

\footnotetext{
${ }^{33}$ Ministry of Religious Affairs, Al-Qurán dan Terjemahnya.

${ }^{34}$ H. Rahmat Hakim, Hukum Pidana Islam (Fiqih Jinayah) (Bandung: Pustaka Setia, 2000), p. 63.

35 Sjawie, 'Delik Perzinahan, p. 36.

${ }^{36}$ For account of this tension between muslims and nationalists in the 1940s to 1960s, see for instance Ahmad Syafii Maarif, Islam dan Pancasila Sebagai Dasar Negara (Jakarta: LP3ES, 2006).
} 
developments. The first is the emergence of another kind of modern Muslims especially after the demise of Soekarno's regime and the ascendance of Soeharto's repressive rule. The group argue that the most suitable manifestation of Islamic values in Indonesia is by inspiring Indonesia with Islamic values without a necessity for applying Islamic teaching in formal manifestation in politics and law. They believe that democracy and human rights are not only compatible with Islam, but also part of Islamic values. ${ }^{37}$ This neo modernist understanding of Islam is also termed as Islam Kultural. ${ }^{38}$ The notable proponents of this new modern Muslims are Nurcholish Madjid, and Abdurrahman Wahid. ${ }^{39}$ The second is the emergence of religious fundamentalism since the 1970s as it occurred elsewhere in the Muslim world. This fundamentalism initially originate as student discussion groups in campuses. The activities were so discreet that the repressive authority did not detect them until they become a massive movement across campuses in Indonesia. They brought the idea of the application of Islam in every aspect of life, especially commitment to sharia and political Islam. Some of the groups are inspired by Hasan al-Banna's al-Ikhwan al-Muslimun and al-Nabhani's Hizb al-Tahrir with its ultimate goal of establishing caliphate. ${ }^{40}$ The most notable proponent of this neo-fundamentalism is M. Imaduddin Abdulrahim. ${ }^{41}$ Jemaah Tarbiyah activists, with which these neo-fundamentalists are often termed, believe that one of the avenues of their struggle for Islamizing Indonesia is through politics and that shari'a should be implemented. For that purpose, they establish Partai Keadilan Sejahtera (PKS Justice and Prosperous Party). Many activists of the movement now become bureaucrats, academics and politicians. They keep

37 See for instance Fachry Ali and Bachtiar Effendy, Merambah Jalan Baru Islam: Rekonstruksi Pemikiran Islam Indonesia Masa Orde Baru (Bandung: Mizan, 1986) and Robert W. Hefner, Civil Islam: Muslims and Democratization in Indonesia (Princeton and Oxford: Princeton University Press, 2000).

38 Arskal Salim and Azyumardi Azra (eds), Shari'a and Politics in Modern Indonesia (Singapore: ISEAS, 2003)

39 Greg Barton, Índonesia's Nurcholish Madjid and Abdurrahman Wahid as Intellectual úlama': The meeting of Islamic Traditionalism and Modernism in neoModernist Thought', Studia Islamika, 4, 1 (1997), pp. 29-81

40 Abdul Aziz, Gerakan Islam Kontemporer di Indonesia (Jakarta: Pustaka Firdaus, 1994).

${ }^{41}$ Jimly Asshiddiqie et al, Bang 'Imad: Pemikiran dan Gerakan Dakwahnya (Jakarta: Gema Insani Press, 2002). 
campaigning their version of Islam, including the implementation of Islamic law. ${ }^{42}$

The disparity between these two conflicting standpoints reflect sharply in many issues, including the issue of applicability of Islamic criminal law in Indonesia. The modernist-liberal clearly consider that such application is unnecessary and even contradictory to their modern Islamic views that any law should uphold human rights. Textual interpretation of Islamic criminal law is clearly contradictory to human rights. Islamic criminal law still prohibits what is now considered private matters such as fornication and adultery. Moreover, its punishments are harsh and inhuman, such as amputation and stoning to death. They refer to several well-known advocates of abolition of death penalty such as Abdullahi Ahmed al-Naim, Ziba Mir-Hosseini and Tariq Ramadan. Al-Na'im, for instance attributes the available concept of Islamic law proposed by early Muslim jurists as historical. He further asserts that this ancient "Sharia violates some of the most fundamental international human standards". He shows that the ongoing practices of the application of Islamic criminal law in Sudan prove his point. The application has breached private lives of individual Muslims and the punishment is inhuman, cruel, and sadistic to modern standard. It only creates disagreement and misgivings from majority Muslims in Sudan. ${ }^{43}$

For it to be implemented in today context, al-Naim further suggests Islamic law must be reformulated in such a way that will be considered Islamic but at same time supportive of modern legal establishments. He later suggested that such endeavor will require departure from plenty aspects of historical shari'a and embracement of more essential Islamic values. ${ }^{44}$ In other occasion, he asserts that historical shari'a is bound to its context. Citing his mentor Mahmoud Mohammad Taha, he argues that today context is different. Thus,

\footnotetext{
${ }^{42}$ For insider account of PKS, see Yon Machmudi, Islamising Indonesia: the Rise of Jemaah Tarbiyah and the Prosperous Justice Party (PKS) (Canberra: ANU E-Press, 2008). For outsider analysis of PKS see M. Imdadun Rahmat, Ideologi Politik PKS: Dari Masjid Kampus ke Gedung Parlemen (Yogyakarta: LKiS, 2008) and Akh. Muzakki, 'Islamisme dan Politisasi Agama Model PKS dalam Pilpres 2009', Islamica, 5, 1 (September 2010), pp. 61-76.

43 Abdullahi Ahmed An-Na'im, Toward an Islamic Reformation: Civil Liberties, Human Rights, and International Law (Syracuse: Syracuse University Press, 1990), p. 107.

${ }^{44}$ Ibid., pp. 9-10
} 
while maintaining that Islam fits all ages and places, the quest of modern Muslim jurist is discovery the eternal and universal message of Islam, such as justice and equality. Therefore, when justice and equality are achieved in a given law, it should be deemed Islamic. ${ }^{45}$

In the same vein, Ziba Mir-Hosseini, a renowned Iranian feminist, argues that in essence Islam has improved the law of adultery of preIslamic Arabia. She argues that Islamic law on adultery actually prevents misery and hardship that was inflicted by this pre Islamic patriarchal Arab law upon women who committed adultery. They would be locked up in entire their lives with no hope of rehabilitation. Pre-Islamic Arab consider adultery as a tribal offence not a sin. Promiscuity is rampant involving men and women, free and slave alike. Islam regulates this and intend to protect women's rights and wellbeing. Among the avenue of this protection are harsh punishment for adulterer, the strict adultery judicial investigation procedure, and defamation charges with reasonably harsh punishment. All of which detach women from being easily convicted in adultery charges. ${ }^{46}$ Hosseini even concludes that Islamic criminal establishment on adultery is not meant for application, it is just a mere deterrence instead. Therefore, she argues that the modern application of Islamic criminal law of adultery by some Muslim-populated countries is ahistorical and contrary to the true intention of the law itself. Furthermore, in modern context, Muslims simply cannot ignore international human rights establishment and societal change that has shifted from patriarchal culture. ${ }^{47}$

Similarly, citing the majority of Muslim jurists, Tariq Ramadan also believe that Islamic criminal law, including that of adultery, is never be implemented past and present of Muslim world because "the conditions under which it should be implemented are nearly impossible to reestablish". ${ }^{48}$ Thus, it only serves as deterrence.

\footnotetext{
45 Abdullahi Ahmed An-Na'im, 'Íslamic Law, International Relations and Human Rights: Challenge and Response', Cornell International Law Journal, 20, 2 (Summer 1987), p. 334.

46 Ziba Mir-Hosseini and Vanja Hmamzic, Control and Sexuality: the Revival of Zina Laws in Muslim Contexts (London: WLUML, 2010), pp. 14-16.

${ }^{47}$ Ibid.

48 Tariq Ramadan, An International Call for Moratorium on Corporal Punishment, Stoning and the Death Penalty in the Islamic World, in http://tariqramadan.com/an-international-call-
} 
Therefore, Muslims should focus on the creation of justice and equality. The practice on the ground shows that Islamic criminal law only applied to the poor, women and the minors (traffickers, political prisoners, delinquents). On that basis, he calls for the moratorium of corporal punishment, stoning and death penalty. He further assert that his campaign does not contradict the shari'a because as it is welldocumented in history that caliph Umar ibn al-Khattab once postponed the application of certain aspects of Islamic criminal law because of unfavorable social condition. Ramadan insists that Islamic criminal law must not be used as a tool for oppression. The oppressor and the powerful in certain Muslim countries have been using this law to unjustly degrade and subjugate others. ${ }^{49}$

All of these insights echoes loudly in the opinions of modern and progressive Muslims in Indonesia, such as Lily Zakiyah Munir and Saiful Mujani. Lily Zakiyah Munir, a Muslim feminist for instance, believes that application of textual approach of Islamic criminal law would only discriminate women. She asserts that the necessity is upholding the essence of Islamic law, which is justice and equality. She observes that the implementation of certain aspect Sharia in Aceh, including prohibition of khalwat and lashing punishment, is heavily political and symbolic. The essence of the shari'a, which is justice and equal distribution of prosperity, is lacking. With the special autonomy that grant Aceh the right to control nearly all of its revenues of its abundant natural resources, people in Aceh remain reasonably poor. Many of them complained the application of shari'a that focused on trivial aspects such as veiling and indecency. ${ }^{50}$ Likewise, being a sociologist, Saiful Mujani reviewed experiences of Muslim countries that applies Islamic criminal law, such as Saudi Arabia, Iran, Sudan and Malaysia. He concludes that the implementation of Islamic does not relates closely to prosperity and justice. Moreover, the implementation of Islamic law is often accomplished by compulsion and force. ${ }^{51}$

for-moratorium-on-corporal-punishment-stoning-and-the-death-penalty-in-the-islamic-world/.

49 Ibid.

${ }^{50}$ Lily Zakiyah Munir, 'Simbolisasi, Politisasi dan Kontrol terhadap Perempuan di Aceh, in Burhanudin (ed), Syariat Islam: Pandangan Muslim Liberal (Jakarta: Jaringan Islam Liberal and the Ford Foundation, 2003), p. 236.

51 Saiful Mujani, 'Syari'at Islam dalam Perdebatan', in Burhanudin (ed), Syari'at Islam, p. 39 
On the other hand, the proponent of application Islamic criminal law believes that it is integral part of Islamic teaching. Ismail Yusanto, the spokesperson of Indonesian Hizb al-Tahrir for instance, states that applying shari'a, including that of Islamic criminal law is the only solution to the multi-dimensional crisis that Indonesia is facing. Such an application necessitates an Islamic political framework of caliphate..$^{2}$ Activists of Jemaah Tarbiyah within PKS also believe that shari'ah is the solution. However, as opposed to Hizb al-Tahrir, those activists maintain that the implementation of shari'ah should be done in a peaceful and constitutional way. In addition, the universal and values of shariah, such as prosperity, justice, security and peace, must entail in its implementation. They acknowledge that budud (Islamic criminal law) is part of shari'ah but, shari'ah is broader than that. Still, budud may not be applied as long as there is still economic and social injustice..$^{53}$

Upon these two conflicting opinions, as well as views of secular nationalists, silent majority Muslims, and non-Muslims, Indonesian legislation program for criminal code is unfolded.

\section{Adultery and Fornication in the Draft of Criminal Code}

Throughout the history of Indonesia since pre-colonial period, Islamic law, in one way or another, has become the law of the community. The colonial period in which Islamic law was reduced to be part of customary law and subordinate to Dutch law, certain aspects of Islamic law remained practiced by Indonesian Muslims. ${ }^{54}$ Therefore, as living law practiced by Muslims in Indonesia, certain aspects of Islamic law is potentially adopted as national law. There are plenty precedents for this, especially in private matters, in which the state accommodated Islamic law, such as Family Act No. 1/1974, Islamic Family Court No.7/1989, Zakat Act No. 38/1999, Shari'ah Banking Act No. 21/2008, etc.

\footnotetext{
52 Ismail Yusanto, 'Selamatkan Indonesia dengan Syariat Islam', in Burhanudin (ed), Syariat Islam, pp. 144-6.

53 Yon Mahmudi, Islamising Indonesia, pp. 197-5

${ }^{44}$ Bani Syarif Maula, 'Realitas Hukum Islam dalam Konfigurasi Sosial dan Politik di Indonesia: Perspektif Sosiologi hukum tentang perkembangan hukum Islam di Indonesia', Hermenia: Jurnal Kajian Islam Interdisipliner, 2, 2 (July-December 2003), pp. $249-50$.
} 
Many of these Acts are products of national legislation project that has started in 1976. ${ }^{55}$ This program apparently progressed quite slowly so that a special Act on legal creation passed in 2004 to accelerate the passage of national acts. The draft of Criminal Code is included in the medium priority of 2004-2009.56 Apparently, though, the draft has been discussed years before 2004, as early as 1968. The draft was continuously reviewed by experts several times until 1993. The Ministry of Law finalized the draft to become the bill of criminal code, but did not propose the bill for discussion with the legislative body..$^{57}$

After another drafting in 2000 to accommodate critiques, it was only in 2004 that the bill of criminal code was listed for discussion with the legislative body. The fact that it takes years for drafting and discussion shows potential issued in the draft. This bill later reviewed and the last draft in 2013 resubmitted by the government to the legislative for another discussion. In its submission remarks to the legislative, ministry of law and human rights states that the aim of the bill is not only de-colonialization of the law, but also democratization of criminal law, its consolidation, adaptation and harmonization. The bill acknowledges the crimes based on the living law of society inspired by national philosophy of Pancasila and upholds international general legal principles. In its official draft of academic document prepared by National Body of Legislation (Badan Pembinaan Hukum Nasional $\mathrm{BPHN}$ ), the legislation on adultery is inspired by several norms, including especially the values of Indonesian community values on prohibition of adultery and indecency. The document also explicitly states that prohibition of cohabitation is derived from value of customary law widely held by Indonesian society..$^{58}$ Since customary law and values of Indonesian community is heavily influenced by Islam, the accommodation of Islamic law is inevitable. On that note, Professor Oemar Seno Adji, the minister of Justice from 1966 to 1974 and head of Supreme Court from 1974 to 1982, is quoted by the document as having insisted on the crucial role of religious values in

\footnotetext{
${ }^{55}$ BPHN, Tiga Dekade Prolegnas dan Peran PBHN, p. iv

56 Ibid., p. 53

57 Sri Hartini, 'Perbuatan Pidana Kesusilaan dalam Rancangan Undang-Undang KUHP', Jurnal Civics, 1, 2 (December 2004), p. 216.

58 BPHN, Draft Naskah Akademik Rancangan Kitab Undang-Undang Hukum Pidana (KUHP), (Jakarta: BPHN, 2015), pp. 237-238.
} 
determining indecency crime. ${ }^{59}$ The bill then reverted to the government after the legislatives objected issues in the bill, especially on corruption articles. In 2015, government resubmitted the bill for third time to the legislative. The draft of adultery articles, though, does not change considerably since 1993 to 2015.

The indecency crime in the 2013 bill of Criminal Code is located in chapter XVI. It consists of public indecency (pornography), adultery (and fornication), kinds of sexual abuse, prostitution, incest, sexual harassment, rape, cohabitation, sodomy, illegal contraception, liquor abuse, begging, mistreatment of animal, and gambling. If adultery and fornication are concerned, the bill, though, partially adopt the position of conservative Muslims since it is also the aspiration of customary law at large. The offence of adultery (and fornication) in the bill is stipulated in article 483 as follows: ${ }^{60}$

(1) Shall be punished because of zina (adultery and fornication), by a maximum imprisonment of five years:

a. any married man conduct sexual relationship with any woman who is not his wife;

b. any married woman conduct sexual relationship with any man who is not her husband;

c. any single man who conducts sexual relationship with a woman knowing that the guilty co-partner is married woman;

d. any single woman who conducts sexual relationship with a man knowing that the guilty co-partner is a married man; or

e. any man and any woman who are not married conduct sexual relationship.

(2) No prosecution shall be instituted against the criminal act as stipulated in verse (1) unless by complaint of the insulted spouse or the insulted third party.

(3) Upon the complaint as mentioned in verse (2), the articles of 25, 26 and 28 do not apply. ${ }^{61}$

(4) The complaint may be withdrawn as long as the judicial investigation has not commenced.

\footnotetext{
59 Ibid., p. 239

${ }^{60}$ BPHN, Rancangan Undang-Undang tentang Hukum Pidana (Jakarta: BPHN, 2013).

${ }^{61}$ These three articles regulates general procedure of complaint. The exclusion of these articles from adultery offences potentially creates legal uncertainty and subjectivity on the procedure of adultery investigation.
} 
The article 483 on adultery departs from the existing criminal code in several aspects. The first concerns the punishment from a maximum nine months to a maximum of five years. The severer punishment, though, does not introduce adultery punishment in Islamic criminal law of lashing and stoning. This, at least shows that the amendment of adultery offence in the bill does not necessarily adopt Islamic criminal law. Instead, customary law and human rights consideration are also influential. The second is the inclusion of fornication (sexual relationship between unmarried couple) in the category in this offence. Admittedly, this is an accommodation of the definition of zina in Islamic criminal law, which consists of adultery and fornication. The third is the inclusion of the third party who may file complaint an adultery act. This expansion, too, is to accommodate Islamic criminal law, in which the complaint of adultery and fornication may be filed by any fellow competent Muslims who witness the offence. The fourth is about the procedure of judicial investigation. Interestingly, the bill excludes general procedure of judicial investigation of criminal code in articles 25, 26 and 28 from adultery cases. This may result in two opposing results. It may result in the use of procedure of investigation in Islamic criminal law, which is strict and difficult. Thus, in such situations, adultery cases will not be conveniently complained. However, since it is not clearly stipulated, adultery cases will be carelessly filed. This, in turn, will put the accused and the victim in legally unfortunate situation.

In addition to article 483 on adultery and fornication, the bill also introduces cohabitation as crime in article 485. ${ }^{62}$ Interestingly, unlike adultery and fornication, which is complaint based-crime, the crime of cohabitation is considered formal crime. It means that it does not need any complaint to prosecute the act. The punishment for this offence is a maximum of one year imprisonment or fined at Category II (maximum of IDR 7.500.000,00 - seven million and five hundred thousand rupiah).

The crime of indecency in the bill has been always one of many subjects of long discussion and controversy from the beginning. Secular legal experts, progressive Muslims and non-Muslims insist that

${ }^{62}$ Article 485 stipulates: Everyone who live together as if they are husband and wife outside a legal wedlock is punished by imprisonment maximum of one year or fine at maximum of Category II. 
indecency regulation should always protect the private aspects of the citizens and should consider the plurality of Indonesian society. ${ }^{63}$ Their criticism is mainly aimed at the expansion of adultery to include fornication. In Islamic criminal law as well as customary law in many Islamized Indonesian cultures, zina applies to both categories, imposing Islamic criminal law will compromise civil rights and negate the plurality of Indonesian society. Some legal experts consider the adultery articles in the bill of criminal code as over criminalization. Moreover, they assert that a maximum five years imprisonment for adultery and fornication is so severe that equaling punishment of theft. ${ }^{64}$ In addition, the expansion of plaintiffs to include the third party is risky because it will be breach to private lives of citizens. Thus, instead of safeguarding civil rights and privacy of the citizens, the state has gone too far in regulating private and personal aspects of the citizens. In doing so, the state is prone to committing human rights violation. ${ }^{65}$

On the other hand, conservative Muslims as well as fundamentalists are reasonably pleased with the expansion of adultery definition in the bill. They realizes that the full-scale of Islamic criminal law cannot fully adopted in the bill. Even though Muslims are majority, Indonesia is not an Islamic state after all. Moreover, several groups in the society disagree with this expansion. Therefore, the conservatives and fundamentalists perceive the bill as the most that can be achieved in the context. For them, it is essential to have adultery and fornication criminalized since the acts are contradictory to Islamic morality. ${ }^{66}$ Considering that the Islamic criminal law is not fully applied, adultery criminalization in the bill cannot be categorized as budud anymore,

\footnotetext{
${ }^{63}$ J.E Sahetapy, a legal expert who happens to be a Christian, for instance, argue that criminalizing fornication will eventually criminalizing so many people from Sabang To Merauke because many people now do not subscribe to their traditional legal custom as well as religious law on this issue. According to Sahetapy, religion may inspire the law but not on its substance, because Indonesia is not a theocracy. Read his article entitled "KUHP, Zina dan Zina, published in Jawa Pos on 18 November 2003.

${ }^{64}$ Supriyadi Widodo Eddyono et.al, Meninjan Kebijakan Kriminalisasi dalam RKUHP 2015 (Jakarta: Institute for Criminal Justice Reform, 2015), p. 23.

${ }^{65}$ Miko S. Ginting and Supriyadi Widodo Eddyono, Mendorong Pembahasan RKUHP Yang Efektif dan Berkualitas (Jakarta: Institute for Criminal Justice Reform, Pusat Studi Hukum dan Kebijakan, and Aliansi Nasional Reformasi KUHP, 2015), p. 23.

66 Sutan Rambe, Proses Akomodasi Hukum Islam ke Dalam Hukum Pidana Nasional', Jurnal Cita Hukum, 2, 2 (December 2015), p. 240.
} 
instead it is relegated to ta'zir (a crime which refers to punishment for offenses at the discretion of the judge or ruler of the state). Neng Djubaedah ${ }^{67}$ from University of Indonesia Law School and Professor Muhammad Amin Suma from Faculty of Islamic Law and Legal Study of State Islamic University Syarif Hidayatullah propose this. ${ }^{68}$

So far, although the draft of adultery articles in the bill is still criticized, the government is somewhat content with the draft, especially when there is no large-scale opposition to the bill from two opposing sides. However, when LGBT (Lesbian Gay Bisexual Transsexual) issue heated last year, things change. The debates surround the indecency resurfaced. Pros and cons stormed mass media. Meanwhile, the bill of Criminal Code is yet to be passed because of both legal and political issue, namely the inclusion of politics-sensitive corruption crime in the bill. ${ }^{69}$ a group of Muslim fundamentalists from Jemaah Tarbiyah movement put a motion of judicial review to Constitutional Court (Mahkamah Konstitusi - MK) on the article 284, 285,70 $292^{71}$ of the existing Criminal Code. The demand is greater criminalization of homosexuality, as well as expansion of adultery offence and rape. The motion is made in May 2016 with case number of 46/PUU-XIV/2016.72

The twelve petitioners are from different backgrounds, namely academics, activists, politicians, and homemaker. The main petitioners are Professor Euis Sunarti, M.Si, a professor specializing in family resilience and resources from Bogor Institute of Farming (Institut

${ }^{67}$ Djubaedah, Peræinaan Dalam Peraturan, p. 68.

${ }^{68}$ Muhammad Amin Suma, Kritis Sumbangan Konstruktif terbadap RUU KUHP (Bab XVI bingga Bab XXXIII), Public Expose on the Bill of Criminal Code conducted by Ministry of Justice and Human Rights, Jakarta 08 September 2004.

${ }^{69}$ Read for instance, Tempo.co, 'Mengapa KPK Kukuh Tolak RUU KUHP?', 12 December 2014, https://nasional.tempo.co/read/news/2014/12/12/063628092/mengapa-kpk-kukuh-tolak-ruu-kuhp, viewed on 6 March 2015.

70 Article 285: Any person who by using force or threat of force forces a woman to have sexual intercourse with him out of marriage, shall, being guilty of rape, shall be punished with a maximum imprisonment of twelve years.

71 Article 292: Any adult who commits any obscene act with it minor of the same sex whose minority he knows or reasonably should presume, shall be punished by a maximum imprisonment of five years.

${ }^{72}$ Mahkamah Konstitusi Republik Indonesia, Ringkasan Perbaikan Permohonan Nomor 46/PUU-XIV/2016 Perbuatan Perizinaan, Perkosaan, dan Pencabulan. 
Pertanian Bogor - IPB), Rita Hendrawaty Soebagio SpPsi MSi, secretary general of Aliansi Cinta Keluarga (AILA), an NGO working on family wellbeing, and Dr. Sitaresmi Sulistyawati Soekanto, a politician from Justice and Prosperity Party (Partai Keadilan Sujahtera - PKS). ${ }^{73}$ They argue that the articles in the Criminal Code regulating those three offences has been contradictory to Constitution, notably article 1(3) (supremacy of law), 28B, C, D, G, H, J (protection of civil rights) and 29 (religious foundation of the state). They assert that those offences (adultery, rape and homosexuality) threaten national resilience. Moreover, all existing religions in Indonesia denounce the offences. Thus, there is no point in conserving the Criminal Code which is made by the Dutch that clearly has different values.

Based on the argument, the petitioners argue that sociologically speaking, Indonesian society understand zina to include adultery and fornication, whereas article 284 of the Criminal Code only criminalizes adultery. They insists that rape also include same-sex rape, not limited to different sex rape as regulated in article 285 of the Criminal Code. Consequently, they also insist the amendment of homosexual offence in article 292 of the Criminal Code to criminalize all kinds of homosexually, not limited to cases where minor is involved. This judicial review is still in the early hearing process and it has already sparked fierce debates on the matter again.

\section{Conclusion}

The accommodation of Islamic criminal law of adultery in Indonesian criminal law is controversial in Indonesia. Indonesia is certainly not an Islamic state, but it is not a purely secular state either. The spectrum of Indonesian society also reflects that. On the issue of accommodating Islamic criminal law in the draft of criminal law, there are pros and cons. However, the accommodation of Islamic criminal law of adultery has managed to expand the definition to include fornication, to extend the maximum imprisonment from 9 months to 5 years, and to criminalize cohabitation. Unsurprisingly, the notoriously cruel punishment of Islamic criminal law is not accommodated.

\footnotetext{
${ }^{73}$ Mahkamah Konstitusi Republik Indonesia, Risalah Sidang Perkara Nomor 46/PUUXIV/2016, peribal pengujian undang-undang nomor 1 tabun 1946 tentang peraturan bukum pidana atau kitab undang-undang bukum pidana.
} 
At least, the bill has observed the basic values of Islamic criminal law, notably outlawing adultery, fornication and cohabitation. This is so far a success for conservatives-fundamentalists, although the bill is not yet passed. However, this success is not without opposition from liberals, seculars, and progressive Muslims who keep opposing those immensely Islamic articles because of their contradiction to plurality of Indonesia and civil rights. The debate reruns when a group of conservatives-fundamentalists proposed judicial review of adultery articles of the Criminal Code to Constitutional Court. Although quite likely that the aforementioned accommodation of Islamic criminal law of adultery, fornication, and cohabitation is inevitable, the bill of criminal law has not been passed and the judicial review is in the hearing process until today. []

\section{References}

\section{Books and Articles}

Ali, Fachry and Bachtiar Effendy. Merambah Jalan Baru Islam: Rekonstruksi Pemikiran Islam Indonesia Masa Orde Baru. Bandung: Mizan, 1986.

An-Na'im, Abdullahi Ahmed. 'Islamic Law, International Relations and Human Rights: Challenge and Response.' Cornell International Law Journal. 20, 2 (Summer 1987).

--------. Toward an Islamic Reformation: Civil Liberties, Human Rights, and International Law. Syracuse: Syracuse University Press, 1990.

Asshiddiqie, Jimly. Bang 'Imad: Pemikiran dan Gerakan Dakwahnya. Jakarta: Gema Insani Press, 2002.

Aziz, Abdul. Gerakan Islam Kontemporer di Indonesia. Jakarta: Pustaka Firdaus, 1994.

Barton, Greg. "Indonesia's Nurcholish Madjid and Abdurrahman Wahid as Intellectual úlama': The meeting of Islamic 'Traditionalism and Modernism in neo-Modernist Thought.' Studia Islamika, 4, 1 (1997).

Bezouskova, Lenka and Antonin Lojek. 'Adultery and Fornication in Historical Perspectives. The Law Quarterly, 4 (2015). 
BPHN. Draft Naskah Akademik Rancangan Kitab Undang-Undang Hukum Pidana (KUHP). Jakarta: BPHN, 2015.

-------. Rancangan Undang-Undang tentang Hukum Pidana. Jakarta: BPHN, 2013.

\section{--------. Tiga Dekade Prolegnas dan Peran PBHN. Jakarta: BPHN, 2008.}

Djubaedah, Neng. Perzinaan dalam Peraturan Perundang-undangan di Indonesia Ditinjau dari Hukum Islam. Jakarta: Kencana, 2010.

Eddyono, Supriyadi Widodo, et.al. Meninjau Kebijakan Kriminalisasi dalam RKUHP 2015. Jakarta: Institute for Criminal Justice Reform, 2015.

Erwin, Muhamad. Filsafat Hukum Refleksi Kritis Terhadap Hukum. Jakarta: RajaGrafindo Persada, 2011.

Faizal, Enceng Arif and Jaih Mubarok. Kaidah Fiqh Jinayab; Asas-Asas Hukum Pidana Islam. Bandung: Pustaka Bani Quraisy, 2004.

Ginting, Miko S. and Supriyadi Widodo Eddyono, Mendorong Pembahasan RKUHP Yang Efektif dan Berkualitas. Jakarta: Institute for Criminal Justice Reform, Pusat Studi Hukum dan Kebijakan, and Aliansi Nasional Reformasi KUHP, 2015.

Hakim, H. Rahmat. Hukum Pidana Islam (Fiqih Jinayah). Bandung: Pustaka Setia, 2000.

Harkrisnowo, Harkristuti. "Tindak Pidana Kesusilaan dalam Perspektif Kitab Undang-Undang Hukum Pidana." in Muhammad Amin Suma (ed.). Pidana Islam di Indonesia; Peluang, Prospek dan Tantangan. Jakarta: Pustaka Firdaus, 2001.

Hartini, Sri. 'Perbuatan Pidana Kesusilaan dalam Rancangan UndangUndang KUHP.' Jurnal Civics, 1, 2 (December 2004).

Hefner, Robert W. Civil Islam: Muslims and Democratization in Indonesia. Princeton and Oxford: Princeton University Press, 2000.

Kusumaatmadja, Mochtar. Konsep-Konsep Hukum dalam Pembangunan. Bandung: Alumni, 2006.

Lamintang, P.A.F. and Theo Lamintang. Delik Delik Khusus Kejahatan Melanggar Norma Kesusilaan dan Norma Kepatutan. Jakarta: Sinar Grafika, 2009.

Ma'luf, Louis. al-Munjid fi al-Lughah wa al- A'lam. Beirut: Dar alMasyriq, 1996. 
Ishaq

Maarif, Ahmad Syafii. Islam dan Pancasila Sebagai Dasar Negara. Jakarta: LP3ES, 2006.

Machmudi, Yon. Islamising Indonesia: the Rise of Jemaah Tarbiyah and the Prosperous Justice Party (PKS). Canberra: ANU E-Press, 2008.

Mahkamah Konstitusi Republik Indonesia. Ringkasan Perbaikan Permohonan Nomor 46/PUU-XIV/2016 Perbuatan Perzinaan, Perkosaan, dan Pencabulan.

---------. Risalah Sidang Perkara Nomor 46/PUU-XIV/2016, perihal pengujian undang-undang nomor 1 tahun 1946 tentang peraturan bukum pidana atau kitab undang-undang hukum pidana.

Mardani. Penyalahgunaan Narkoba dalam Perspektif Hukum Islam dan Hukum Pidana Nasional. Jakarta: RajaGrafindo Persada, 2008.

Maula, Bani Syarif. 'Realitas Hukum Islam dalam Konfigurasi Sosial dan Politik di Indonesia: Perspektif Sosiologi hukum tentang perkembangan hukum Islam di Indonesia.' Hermenia: Jurnal Kajian Islam Interdisipliner. 2, 2 (July-December 2003).

Mir-Hosseini, Ziba and Vanja Hmamzic. Control and Sexuality: the Revival of Zina Laws in Muslim Contexts. London: WLUML, 2010.

Mujani, Saiful. 'Syari'at Islam dalam Perdebatan.' in Burhanudin (ed). Syariat Islam: Pandangan Muslim Liberal. Jakarta: Jaringan Islam Liberal and the Ford Foundation, 2003.

Munajat, Makhrus. Hukum Pidana Islam di Indonesia. Yogyakarta: Teras, 2009.

Munir, Lily Zakiyah. 'Simbolisasi, Politisasi dan Kontrol terhadap Perempuan di Aceh.' in Burhanudin (ed). Syariat Islam: Pandangan Muslim Liberal. Jakarta: Jaringan Islam Liberal and the Ford Foundation, 2003.

Muzakki, Akh. 'Islamisme dan Politisasi Agama Model PKS dalam Pilpres 2009.' Islamica, 5, 1 (September 2010).

Packer, Herbert L. The Limits of the Criminal Sanction. California: Stanford University Press, 1968.

Rahmat, M. Imdadun. Ideologi Politik PKS: Dari Masjid Kampus ke Gedung Parlemen. Yogyakarta: LKiS, 2008.

Ramadan, Tariq. An International Call for Moratorium on Corporal Punishment, Stoning and the Death Penalty in the Islamic World. in 
http://tariqramadan.com/an-international-call-for-moratoriumon-corporal-punishment-stoning-and-the-death-penalty-in-theislamic-world/.

Rambe, Sutan. 'Proses Akomodasi Hukum Islam ke Dalam Hukum Pidana Nasional.' Jurnal Cita Hukum, 2, 2 (December 2015).

Reksodiputro, Mardjono. Hak Asasi Manusia Dalam Sistem Peradilan Pidana. Jakarta: Pusat Pelayanan Keadilan dan Pengabdian Hukum Universitas Indonesia, 1994.

Republika Online, 63 Persen Remaja Berbubungan Sex (20 December 2008), http://www.republika.co.id/berita/shortlink/21526, viewed on 21 February 2016.

Sabiq, Al-Sayyid. Fiqh al-Sunnah. Cairo: Dar al-Hadits, 2004.

Sahetapy, J.E. "KUHP, Zina dan Zina." in Jawa Pos, 18 November 2003.

Salim, Arskal and Azyumardi Azra (eds). Shari'a and Politics in Modern Indonesia. Singapore: ISEAS, 2003.

Sjawie, Hasbullah F. 'Delik Perzinahan Menurut KUHP dan Perkembangannya.' Hukum dan Pembangunan, 1, 26 (February 1996.

Soejono. Kejahatan \& Penegakan Hukum di Indonesia. Jakarta: Rineka Cipta, 1996.

Soekanto, Soerjono. Pokok-pokok Sosiologi Hukum. Jakarta: RajaGrafindo Persada, 2001.

Soesilo, R. Kitab Undang-undang Hukum Pidana (KUHP) serta Komentarkomentarnya Lengkap Pasal demi Pasal. Bogor: Politeia, n.d.

Sukandy, Muh. Syarief. Terjemah Bulughul Maram Fiqih Berdasarkan Hadits. Bandung: Al-maárif, 1978.

Suma, Muhammad Amin. Kritis Sumbangan Konstruktif terbadap RUU KUHP (Bab XVI hingga Bab XXXIII), Public Expose on the Bill of Criminal Code conducted by Ministry of Justice and Human Rights, Jakarta 08 September 2004.

Sweeny, JoAnne. 'Undead Statutes: The Rise, Fall and Continuing Uses of Adultery and Fornication Criminal Laws.' Loyola University Chicago Law Journal, 46 (2014). 
Ishaq

Tempo.co, 'Mengapa KPK Kukuh Tolak RUU KUHP?', 12 December 2014,

https://nasional.tempo.co/read/news/2014/12/12/063628092 Lmengapa-kpk-kukuh-tolak-ruu-kuhp, viewed on 6 March 2015.

Tongat. Pidana Kerja Sosial dalam Pembaharuan Hukum Pidana Indonesia. Jakarta: Djambatan, 2002.

Yusanto, Ismail. 'Selamatkan Indonesia dengan Syariat Islam.' in Burhanudin (ed), Syariat Islam: Pandangan Muslim Liberal. Jakarta: Jaringan Islam Liberal and the Ford Foundation, 2003. 